\title{
Evaluasi Sistem Informasi Pelayanan Rekam Medis di RSJ Prof. Dr. V.L. Ratumbuysang Provinsi Sulawesi Utara dengan Pendekatan Hot Fit Model
}

\author{
Donny Makalalag*, Farid Agushybana**, Atik Mawarni** \\ *Staf Pengajar Politeknik Kesehatan Kemenkes Manado \\ **Fakultas Kesehatan Masyarakat Universitas Diponegoro \\ Email:donny_mg@yahoo.co.id
}

\section{ABSTRACT:}

Medical Record Information System Service at Prof. Dr. V.L. Ratumbuysang Mental Hospital North Sulawesi Province had not run as expected. Indicated by the differences in patient data in the recording and the medical records. Factors that allegedly affect are human, organization and technology. This study aims to evaluate medical record service information system with the HOT FIT Model approach and its benefits.

This was a qualitative study. Data collected through in depth interviews and analyzed by content analysis method. Research subjects were 1 admin officer and 3 archival officers as main informants and the chief of medical record service, the head medical services division and an assistant director of medical services and nursing as the triangulation informants.

The results showed that the medical record service information system had facilitated the work but the knowledge and skills of the officers were still lacking. Organizational factors were supported but the budget was still lacking in system development. Technological factors had not run optimally because the LAN network did not work. The quality of the information had not been met because the data of the visits should be checked again before used for decision making. Quality of service was not maximal yet, because the connectivity between medical record and polyclinic was impaired, then the officer used manual form.

It can be concluded that the hospital need to increase the staff knowledge and allocate funds for improvement and development of information systems or cooperate with other parties in system maintenance.

Keyword: Medical Record Information System; Evaluation; Hot-Fit Model

\section{PENDAHULUAN}

Sebagai Rumah Sakit rujukan bidang kesehatan jiwa di Provinsi Sulawesi Utara, Rumah Sakit Prof Dr. V.L Ratumbuysang merupakan Rumah Sakit tipe B dengan wilayah cakupan meliputi daerah lintas Provinsi Sulawesi Utara antara lain Provinsi Gorontalo, Provinsi Maluku Utara dan Provinsi Papua Bagian Utara.

Dokumen rekam medis merupakan salah satu bukti tertulis tentang proses pelayanan yang diberikan oleh dokter. Di dalam rekam medis berisi data klinis pasien selama proses diagnosis dan 
pengobatan (treatment). Oleh karena itu setiap kegiatan pelayanan medis harus mempunyai rekam medis yang lengkap dan akurat untuk setiap pasien dan setiap dokter wajib mengisi rekam medis dengan benar, lengkap dan tepat waktu. ${ }^{1,2}$

Untuk memenuhi kebutuhan ketersediaan data rekam medis yang terintegrasi maka Rumah Sakit Jiwa Prof. Dr. V.L. Ratumbuysang dalam menyediakan informasi sudah menggunakan SIMRS (Sistem Informasi Manajeman Rumah Sakit) sejak tahun 2014. SIMRS ini diharapkan dapat menyediakan informasi yang benar dan akurat. Untuk mendukung kegiatan SIMRS, Rumah Sakit sudah menyediakan Hardware, Software dan Brainware. Studi pendahuluan terhadap pelaksanaan pengelolaan sistem informasi Rumah Sakit di unit rekam medis ditemukan beberapa masalah, seperti; perbedaan jumlah pasien antara bagian pendaftaran/pencatatan (loket) dengan bagian rekam medis, adanya tugas rangkap dari pengguna, laporan masih dicatat secara manual.

Permasalahan ini mendorong peneliti untuk melakukan evaluasi apakah sistem ini telah berjalan dengan baik serta dan meneliti penyebab-penyebab timbulnya permasalahan yang timbul selama ini.

Penelitian dilakukan dengan menggunakan pendekatan HOT (Human, Organization,Technology) Fit Model. Dengan HOT fit model diharapkan dapat mengungkap penggunaan sistem oleh manusia (brainware) dengan dukungan organisasi sebagai penyedia layanan serta dukungan penggunaan teknologi (hardware/software) dalam menunjang pelayanan di Rumah Sakit.

\section{METODE PENELITIAN}

Jenis penelitian yang digunakan adalah penelitian deskriptif kualitatif untuk memberikan gambaran kualitas sistem informasi pelayanan rekam medis di Rumah Sakit Jiwa Prof. Dr. V.L. Ratumbuysang Provinsi Sulawesi dengan menggunakan pendekatan HOT (Human, Organization,Technology) Fit Model

Informan utama penelitian adalah pengguna/petugas pelaksana yang berhubungan langsung dengan sistem informasi pelayanan rekam medis di Rumah Sakit Jiwa Prof. Dr. V.L. Ratumbuysang. Jumlah informan utama sebanyak 4 (empat) orang. Informan Triangulasi, adalah pihak yang berperan dalam mendukung keberadaan sistem informasi pelayanan rekam medis di Rumah Sakit Jiwa Prof. Dr. V.L. Ratumbuysang. Jumlah informan triangulasi sebanyak 3 (tiga) orang, yaitu Wakil Direktur bidang Pelayanan Medis dan Keperawatan, Kepala Bidang Pelayanan Medik dan Kepala Instalasi Pelayanan Rekam Medis Rumah Sakit Jiwa Prof. Dr. V.L. Ratumbuysang.

Data primer diperoleh melalui wawancara mendalam dan sedangkan data sekunder didapat dari dokumen yang ada di Rumah Sakit. Data yang terkumpul kemudian dianalisis menggunakan metode analisis isi (content analysis). Metode ini meliputi pengumpulan data, reduksi data, penyajian data dan menarik kesimpulan.

\section{HASIL DAN PEMBAHASAN Karakteristik Informan}

Penelitian dilaksanakan di Rumah Sakit Jiwa Prof. Dr. V.L Ratumbuysang Manado dengan mewawancarai responden berjumlah 7 (tujuh) orang. Penelitian dilakukan di unit pelayanan rekam medis, meliputi 4 petugas yang berhubungan langsung dengan bidang rekam medis (informan utama) dan 3 responden 
(informan triangulasi).

Informan utama berumur rata-rata diatas 25 tahun, dan yang berjenis kelamin perempuan lebih banyak dari yang berjenis kelamin laki-laki. Dilihat dari tingkat pendidikan S1 sebanyak 2 orang, D3 sebanyak 1 orang dan pendidikan SMEA 1 orang. Dari ke 4 informan utama tersebut hanya satu orang yang berlatar belakang pendidikan rekam medis. Ditinjau dari status kepegawaian rata-rata informan utama berstatus PNS dan satu orang lainnya berstatus kontrak. Sedangkan jika dilihat dari masa kerja yang paling lama 7 tahun dan paling sedikit 2 tahun.

Informan triangulasi berumur ratarata berada diatas 50 tahun, dan yang berjenis kelamin perempuan lebih banyak dari yang berjenis kelamin laki-laki. Dilihat dari tingkat pendidikan S1/Dokter sebanyak 2 orang dan SMA 1 orang. Dari ke 3 informan triangulasi berstatus PNS. Jika dilihat dari masa kerja yang paling lama 31 tahun dan paling sedikit 23 tahun.

\section{Faktor Manusia (Human) Pada} Sistem Informasi Pelayanan Rekam Medis

Komponen manusia sebagai penyedia dan pengguna sistem informasi merupakan bagian penting dari sistem informasi. Pemahaman manusia terhadap sistem informasi membantu pengaplikasian suatu sistem dalam institusi. ${ }^{3}$

\section{a. Penggunaan Sistem (System Use)}

Hasil wawancara terhadap
informan utama tentang lamanya penggunaan sistem pelayanan rekam medis dalam sehari sekitar $1-6$ jam setiap hari kerja. Seperti yang disampaikan oleh informan, seperti hasil wawancara dalam kotak 1.

\section{Kotak 1}

...waktu pelayanan mulai di buka jam 08.00

- 14.00, pemakaian sistem sekitar < 6 jam per hari...(IU. A, B, C, D)

Semakin lama masa kerja akan semakin baik karena sudah bisa beradaptasi dengan lingkungan pekerjaan dan sistem kerja yang ada. ${ }^{3}$

Penggunaan sistem sering terhambat karena kekurangan tenaga serta beban tugas tambahan/tugas rangkap dari petugas pelaksana (IU A, B, C, D). Hal ini ditegaskan dalam petikan wawancara dengan informan triangulasi pada kotak 2.

\section{Kotak 2}

...ada sistem rekam medis, tapi kita terkendala kekurangan tenaga terlebih yang memang ahlinya...(IT. A, B)

...masalah kami adalah kekurangan tenaga yang tahu betul tentang rekam medis, untunglah dua tahun terakhir sudah ada pegawai kontrak yang masuk disini lulusan dari D3 Rekam Medis...(IT. C)

Petugas yang berlatar belakang pendidikan rekam medis di rumah sakit jiwa masih kurang, namun dalam dua tahun terakhir sudah ada pegawai kontrak yang membantu di bagian rekam medis.

Penggunaan sistem juga sangat ditentukan oleh pengetahuan dan keterampilan seseorang dalam menggunakan sistem. Hasil wawancara dengan informan utama mengenai pengetahuan dan pelatihan yang pernah diikuti pengguna dalam menjalankan sistem informasi pelayanan rekam medis dapat dilihat pada kotak 3 .

\section{Kotak 3}

... belum pernah mengikuti pelatihan tentang rekam medis,cuma diajari admin bagaimana cara menginput data, selanjutnya belajar sendiri, kalau ada masalah kita bertanya ke admin...(IU. B, C, D)

Pengetahuan dan keterampilan yang dimiliki oleh petugas berbeda-beda 
sesuai dengan latar belakang pendidikan. Dilihat dari pendidikan petugas yang berhubungan langsung dengan rekam medis ada Sarjana Keperawatan, Sarjana Ekonomi, Diploma 3 Rekam Medis dan SMEA. Dari ke 4 (empat) informan utama hanya satu orang yang berlatar belakang pendidikan rekam medis yaitu IU.A. Dilihat dari tingkat pendidikan rata-rata berlatar belakang pendidikan tidak sesuai dengan bidang yang ditekuni dan 1 (satu) orang yang bertugas sebagai admin masih merupakan tenaga kontrak.

Secara umum sistem ini mudah dalam penggunaan, sehingga petugas bisa cepat beradaptasi dan memahami dalam pengoperasian sistem, walaupun petugas belum pernah mengikuti pelatihan yang berhubungan dengan sistem. Dalam menggunakan sistem petugas jarang sekali menggunakan buku panduan (prosedur manual), petugas lebih senang menggunakan keterampilan dari petugas admin, dikarenakan cepat dalam memberikan petunjuk dan lebih cepat dipahami. Hal ini ditegaskan juga oleh informan triangulasi pada kotak 4.

\section{Kotak 4 \\ ...belum pernah dilakukan pelatihan untuk merefresh lagi ilmu tentang rekam medis...(IT. A, B)}

Pengguna sistem sangat berharap adanya perhatian dan dukungan dari atasan dalam pengelolaan sistem pelayanan rekam medis agar menjadi lebih baik.

Pengguna sistem mengharapkan adanya dukungan dari pengambil kebijakan dalam peningkatan dan pengembangan sistem sesuai kebutuhan serta penambahan sumber daya manusia (SDM) yang berkompeten agar sistem yang telah ada dapat berjalan dengan baik.

\section{Kotak 6}

...memang kita kekurangan tenaga ahli bidang rekam medis, untunglah sekarang sudah ada walau hanya pegawai kontrak yang lulusan rekam medis, petugas lainnya beda keilmuan, semua tergantung anggaran... (IT. A, B, C)
Dari wawancara mengenai harapan dari pengguna sistem, diharapkan ada dukungan dari informan triangulasi agar bisa mengadakan penambahan tenaga ahli yang sesuai bidang ilmu rekam medis dan mengikut sertakan petugas dalam pelatihan yang berkaitan dengan sistem pelayanan rekam medis, agar pelayanan bisa maksimal.

Untuk meningkatkan mutu pelayanan Rumah Sakit, seorang pimpinan Rumah Sakit harus memperhatikan sistem informasi Rumah Sakit, salah satunya dengan menempatkan tenaga rekam medis dan informasi kesehatan di tiap - tiap bagian unit rekam medis, di poliklinik rawat jalan, unit rawat inap atau bangsal. Alangkah baiknya pemanfaatan tenaga rekam medis dan informasi kesehatan digunakan di beberapa atau di tiap-tiap bagian di setiap unit pelayanan di rumah sakit. $^{4}$

\section{b. Kepuasan Pengguna (User Satisfaction)}

Tingkat kepuasan pengguna bisa menjadi acuan keberhasilan suatu sistem dan manajemen dalam mendukung pelayanan.

Hasil wawancara dengan informan tentang kepuasan pengguna dapat dilihat dari petikan wawancara pada kotak 7 .

\section{Kotak 7}

...pekerjaan jadi ringan, kalau kita memerlukan data mudah diperoleh...(IU. B, C, D)

...pekerjaan saya sebagai admin bertambah, karena saya juga memegang aplikasi yang berhubungan dengan keuangan...(IU. A) ...mudah dalam pengoperasian sistem informasi, meskipun fasilitasnya belum terlalu lengkap...(IU. A, B, C, D) 
Dari pernyataan diatas dapat dilihat bahwa penggunaan sistem sudah membantu dalam pekerjaan dan mempermudah pengguna dalam mencari data dan informasi mengenai pasien. Sistem juga mudah untuk dipelajari secara mandiri dan jika ada kesulitan yang dihadapi admin sebagai tenaga yang memahami betul tentang rekam medis bersedia membantu. Permasalahan yang dihadapi adalah admin merasa beban tugasnya bertambah karena membantu juga dibagian keuangan. Oleh karena itu penambahan SDM sesuai bidang pekerjaan sangatlah diharapkan agar meringankan beban kerjanya sebagai admin. Untuk tingkat kesulitan penggunaan sistem dan tanggapan penggunaan sistem, petugas merasa mudah dalam pengoperasian dan membantu dalam pekerjaan.

Jika ditinjau dari kepuasan pengguna terhadap sistem yang ada, secara keseluruhan pengguna sistem merasa puas dan terbantu dalam pekerjaan baik dalam pengoperasian sistem yang sederhana dan mudah dipahami serta dalam pencarian data kunjungan pasien.

Harapan dari petugas yang ada di bagian pelayanan rekam medis adalah, adanya dukungan dari manajemen rumah sakit untuk meningkatkan sistem informasi pelayanan rekam medis dengan penambahan SDM, peningkatan keterampilan dan pengetahuan serta perbaikan atau bahkan penambahan fasilitas penunjang pelayanan rekam medis. Sehingga kualitas pelayanan dan informasi yang dihasilkan akan semakin baik.

\section{Faktor Organisasi (Organization)} Pada Sistem Informasi Pelayanan Rekam Medis

Organisasi adalah struktur formal yang stabil dan mengambil sumber daya dari lingkunganserta memprosesnya untuk menciptakan output. ${ }^{3}$

\section{a. Struktur (Structure)}

Hasil wawancara dengan informan mengenai struktur organisasi berkaitan dengan sistem informasi pelayanan rekam medis bertujuan untuk mengetahui dukungan manajemen organisasi serta manfaat sistem dalam mendukung dari sisi manajerial organisasi. Hasil petikan wawancara dapat dilihat pada kotak 8 .

\section{Kotak 8}

...unit rekam medis secara struktur ada di bawah Wadir Bidang Yan. Med dan Keperawatan...(IU. A, B, C, D)

...data dari rekam medis digunakan untuk pembuatan laporan contohnya data kunjungan pasien per tahun...(IU. A, B, C, D)

Unit rekam medis secara struktural berada dibawah Wakil Direktur Bidang Pelayanan Medis dan Keperawatan yang melakukan pelayanan di rumah sakit dan bertanggung jawab langsung ke Direktur serta satuan pengawas internal dan komite medik.

Hal ini di tegaskan juga oleh informan triangulasi dalam petikan wawancara pada kotak 9.

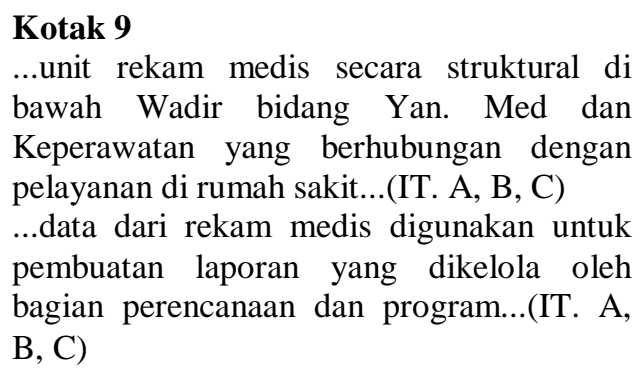

Berdasarkan hal ini dapat dikatakan 
bahwa, unit rekam medis merupakan bagian penting dari organisasi, karena rekam medis mengelola data-data yang dibutuhkan oleh organisasi untuk peningkatan pelayanan dan perencanaan kegiatan kedepannya. Diharapkan SIMRS dapat memberikan informasi yang lebih cepat dan akurat kepada rekam medis dan administrasi serta mempermudah administrasi dan kepala rekam medis dalam mengelola semua data-data di Rumah Sakit. ${ }^{5}$

\section{b. Lingkungan (Environment)}

Lingkungan organisasi berkaitan dengan sistem informasi pelayanan rekam medis meliputi dukungan manajemen organisasi dari sisi pendanaan dan kebijakan.

\section{Kotak 10 \\ ...untuk pengembangan unit rekam medis belum jelas, mungkin berkaitan dengan masalah dana...(IU. A, B, C, D) \\ ...anggaran bersumber dari APBD dan untuk pengembangan unit rekam medis belum ada, nanti diusulkan tahun depan...(IT. A, B) \\ ...dukungan dari manajemen masih kurang, baik SDM maupun masalah dana...(IT. C)}

Dukungan anggaran organisasi terhadap pelayanan rekam medis bersumber dari APBD. Untuk pengembangan atau pengadaan fasilitas penunjang di rekam medis dirasa masih kurang.

Faktor organisasi (Organization) termasuk struktur (Structure) memiliki hubungan yang searah (positif) dan signifikan terhadap lingkungan (Environment) dimana SIMRS diterapkan dan signifikan terhadap Net Benefits (Manfaat sistem). Hal ini dapat dicapai melalui strategi dan manajemen seperti dukungan pemimpin, kerja tim, dan komunikasi efektif yang dibentuk dengan melibatkan peran dan kemampuan karyawan. ${ }^{6}$

\section{Faktor Teknologi (Technology) Pada Sistem Informasi Pelayanan Rekam Medis}

Semakin tepat dan baik kualitas teknologi yang diterapkan pada manusia maka semakin bermanfaat sebuah sistem dikarenakan kepuasan dalam hal penggunaanya, sehingga kualitas kinerja dari karyawan akan meningkat. ${ }^{6}$

Hasil pengamatan dalam penggunaan teknologi diperoleh bahwa sistem informasi pelayanan rekam medis didukung oleh 4 unit komputer klien untuk pelayanan, dengan kapasitas hard disk 500 $\mathrm{gb}$, kapasitas RAM $2 \mathrm{gb}$, prosesor intel pentium 4, layar monitor 4 buah ukuran 21 inc dan 4 buah printer. Fasilitas tersebut ada beberapa yang sudah tidak berfungsi secara maksimal atau rusak.

Pada pendekatan HOT Fit model ini, beberapa aspek yang akan diteliti meliputi kualitas sistem, kualitas informasi dan kualitas layanan yang dihasilkan.

\section{a. Kualitas Sistem}

Kualitas sistem informasi ditinjau dari, kemudahan pengguna, kemudahan untuk dipelajari, respon, kegunaan, ketersediaan basis data dan keamanan, dapat dilihat pada petikan wawancara pada kotak 11.

\footnotetext{
Kotak 11

...kalau dilihat secara tampilan sederhana saja, jadi untuk akses sistem mudah, terus mudah dipelajari...(IU. A, B, C D)

...masalahnya jaringan internet kurang bagus sehingga sistem lama terbuka, apalagi sekarang kabel LAN bermasalah...(IU.A, B, C, D)

...sebagai admin, untuk back up data saya membuat sistem manual menggunakan Excel, agar bisa dibaca secara offline...(IU. A)
} 
Dari pernyataan diatas dapat dikatakan bahwa secara tampilan sistem mudah digunakan dan dipelajari, walaupun masih menghadapi beberapa kendala, seperti jaringan internet yang kurang bagus ditambah dengan kabel LAN yang bermasalah, sehingga mempengaruhi kinerja saat mengakses sistem pada saat pelayanan.

Disisi lain sistem sudah sangat membantu pekerjaan seperti pencarian data pasien. Untuk memback-up admin menggunakan bantuan Ms Excel secara manual.

Untuk fasilitas penyedia basis data dapat dilihat pada petikan wawancara pada kotak 12.

\section{Kotak 12 \\ ...komputer dan laptop yang ada sekarang dalam keadaan baik, walaupun ada komputer yang bermasalah, tapi untuk komputer admin tetap kami jaga sebagai komputer utama...(IU. A, B, C, D)}

Komputer admin sebagai komputer utama penyimpanan data berguna dalam penyediaan basis data, dengan maksud membantu pengguna dalam pekerjaan pelayanan. Hal ini dapat dilihat pada petikan wawancara pada kotak 13 .

\section{Kotak 13 \\ ...sangat membantu sekali saat jam pelayanan, seperti pencarian data pasien, sudah selesai perawatan atau belum. Sebelumnya kita harus buka buku register...(IU. A, B, C, D) \\ ...data pasien kita bagi tiap poli sesuai dengan tindakan...(IU. A, B, C, D)}

Dari sisi keamanan sistem petikan wawancara pada kotak 14 .

\section{Kotak 14}

...semua pegawai di bagian rekam medis bisa membuka sistem, tapi harus melapor ke admin untuk memperoleh username dan password...(IU. A, B, C, D)

...sebagai admin saya tidak sembarang memberikan username dan password, hanya orang-orang tertentu saja, agar pekerjaan saya ada yang membantu...(IU. A)
Sistem keamanan SIMRS didukung dengan memberikan hak akses yang dilindungi oleh username dan password. Hanya orang yang berkewenangan yang dapat membuka sistem atau fitur tertentu.

Jadi secara keseluruhan kualitas sistem informasi pelayanan rekam medis yang digunakan saat ini memang mudah untuk dipelajari apalagi dengan frekuensi pemakaian dan pengetahuan secara mandiri dari setiap pengguna. Masalah yang dihadapi adalah jaringan internet yang kurang baik serta rusaknya jaringan LAN yang berdampak tidak maksimalnya kinerja sistem. Sebagai salah satu solusi admin memback-up data dengan bantuan Ms. Excel secara manual.

SIMRS ini membantu dan mempermudah pekerjaan petugas dalam melihat status pasien yang dirawat di rumah sakit. Mudah dalam mengakses sistem membuat tingkat keamanan sistem harus terlindungi. Untuk itu setiap petugas yang akan menggunakan sistem harus mengakses sistem dengan menggunakan username dan password. Pemberian ijin mengakses sistem menjadi hak petugas yang bertindak sebagai admin. Oleh karena itu keamanan sistem pelayanan rekam medis sudah bisa dipercaya.

Kesimpulan dari kualitas sistem informasi pelayanan rekam medis yang tersedia sudah baik, karena sudah sangat membantu pelayanan seperti ketersediaan data kunjungan pasien, meskipun masih mengalami kendala pada fasilitas pendukung lainnya.

\section{b. Kualitas Informasi}

Kualitas informasi dilihat dari 
kelengkapan, keakuratan/ketepatan, dipercaya/diandalkan dan aktual. Hal ini dimaksudkan agar informasi yang dihasilkan oleh sistem dapat mendukung dan menjawab kebutuhan pengguna dalam membuat pelaporan dan pengambilan keputusan.

Berikut petikan wawancara dengan informan utama mengenai kualitas informasi, seperti pada kotak 15.

\section{Kotak 15}

...untuk output atau informasi, sering kita harus lihat kembali, karena data kunjungan di tiap-tiap poli salah, karena petugas yang kurang paham dan ada data tidak dimasukkan ke rekam medis...(IU. A, B, C, D)

Dari hasil wawancara mengenai kualitas informasi atau output yang dihasilkan dari sistem dapat dikatakan belum maksimal, karena petugas harus melakukan kajian ulang setelah data kunjungan dari tiap-tiap poli masuk ke bagian rekam medis. Proses ini terkendala dengan kurangnya pemahaman dari petugas di bagian poli dalam mengisi format yang diberikan baik secara sistem komputer atau manual. Masalah ini ditegaskan juga oleh informan triangulasi seperti pada petikan wawancara pada kotak 16.

\begin{tabular}{|l}
\hline Kotak 16 \\
...untuk output atau informasi dari rekam \\
medis, kita harus lihat kembali, karena salah \\
data kunjungan di tiap-tiap poli disebabkan \\
data yang terbagi, dan mungkin karena \\
jaringan internet/LAN yang belum \\
diperbaiki, sehingga bagian rekam medis \\
harus memeriksa kembali r data \\
kunjungan...(IT. A, B, C)
\end{tabular}

Hal ini juga dipengaruhi oleh konektivitas antara bagian rekam medis dan poli bermasalah, dikarenakan jaringan LAN yang rusak dan belum diperbaiki. Faktor utama penyebab masalah ini adalah sistem yang belum terintegrasi ke bagian rekam medis akibat rusaknya jaringan internet dan kabel LAN.

Kualitas informasi yang dihasilkan dari sistem pelayanan rekam medis bertujuan untuk mendukung dan menjawab kebutuhan pengguna dalam membuat pelaporan dan pengambilan keputusan. Kualitas informasi pelayanan rekam medis saat ini belum sesuai dengan apa yang diharapkan. Hal ini disebabkan oleh petugas rekam medis harus memeriksa atau mengkaji ulang data kunjungan pasien di tiap-tiap poli, sehingga proses untuk menghasilkan informasi khususnya dalam pelaporan memerlukan waktu. Penyebabnya adalah data yang belum teritegrasi secara menyeluruh ke bagian rekam medis, kerusakan jaringan pendukung seperti LAN dan juga kurangnya SDM yang ada.

Manfaat kinerja sistem kepada petugas sendiri belum dapat mempercepat pekerjaan untuk pengelolaan laporan yang akurat, karena laporan yang dihasilkan masih harus di cross check ulang untuk menghasilkan laporan yang akurat, dalam pengolahan laporan sistem belum dapat menghasilkan laporan secara otomatis, petugas harus mengolah data menjadi laporan secara manual. ${ }^{7}$

Kesimpulan dari kualitas informasi pelayanan rekam medis yang tersedia belum sesuai dengan yang diharapkan, karena petugas rekam medis harus memeriksa atau mengkaji ulang data kunjungan pasien di tiap-tiap poli, sehingga proses untuk menghasilkan informasi khususnya dalam pelaporan masih memerlukan waktu. Hal ini dikarenakan data yang belum teritegrasi secara menyeluruh ke bagian rekam medis. Faktor ini juga disebabkan oleh jaringan pendukung seperti LAN yang bermasalah. 


\section{c. Kualitas Layanan}

Kualitas layanan sistem informasi pelayanan rekam medis yang ingin diperoleh pada wawancara dengan informan ditinjau dari kecepatan respon, jaminan, perhatian, tindak lanjut pelayanan dan rekomendasi pengembangan sistem. Hal ini dapat dilihat pada petikan hasil wawancara dan observasi dengan informan utama pada kotak 17.

\section{Kotak 17 \\ ...secara teknis komputer di kita sudah lumayan bagus, masalahnya sekarang jaringan internet/LAN belum diperbaiki...(IU. A, B, C, D) \\ ...beberapa printer sudah rusak, sudah dicoba diperbaiki tapi sudah tidak bisa, caranya diganti baru...(IU. A, B, C, D) ...sistem dapat berjalan baik jika ada penambahan tenaga yang ahli, mengikuti pelatihan dan adanya perhatian lebih dari rumah sakit...(IU. A, B, C, D)}

Dari hasil wawancara diketahui bahwa secara teknis komputer yang digunakan sudah lumayan bagus, walaupun beberapa fasilitas penunjang lainnya dalam kondisi rusak. Kualitas layanan yang dihasilkan dari sistem informasi pelayanan rekam medis belum maksimal, karena konektivitas antara bagian rekam medis dan poli bermasalah, dikarenakan jaringan LAN yang rusak dan masih kurangnya SDM yang menangani bagian rekam medis, serta masih kurangnya perhatian dari pihak manajemen rumah sakit. Sebagaimana petikan hasil wawancara dengan informan triangulasi pada kotak 18.

\footnotetext{
Kotak 18

...memang dibagian rekam medis sarana penunjangnya sudah lumayan baik, walaupun jaringan internet bermasalah, dan anggaran untuk perbaikan di rekam medis belum menjadi prioritas utama karena keterbatasan anggaran serta adanya rencana pembangunan gedung rumah sakit baru...(IT. A, B)

...semoga tahun depan rekam medis akan lebih baik, apalagi dengan rencana pembangunan gedung rumah sakit baru...(IT. C)
}

Kualitas layanan sistem informasi pelayanan rekam medis secara teknis sudah baik, walaupun ada beberapa komputer dan printer yang rusak serta jaringan LAN yang belum diperbaiki. Sementara untuk dukungan non teknis seperti kekurangan SDM dan anggaran yang tersedia dapat mempengaruhi kecepatan respon pelayanan dan pembuatan laporan. Jika hal ini bisa teratasi maka peningkatan kualitas layanan akan menumbuhkan kepuasan pengguna layanan serta memberikan manfaat bagi institusi. Kualitas layanan suatu sistem juga didukung oleh beberapa hal, antara lain ketersediaan listrik/cadangan listrik, kenyamanan ruang pelayanan serta dukungan penuh dari seluruh petugas yang ada di lingkungan organisasi rumah sakit.

Secara umum hasil penelitian mengenai kualitas layanan sistem belum sesuai dengan yang diharapkan, karena kurangnya SDM yang ada di bagian rekam medis, kurangnya fasilitas pendukung serta kurangnya anggaran untuk peningkatan kualitas layanan.

$$
\text { Dari hasil penelitian yang }
$$
dilaksanakan terhadap sistem informasi dari faktor manusia sangat berpengaruh. Hal ini dipengaruhi oleh latar belakang pendidikan yang tidak sesuai, belum adanya peningkatan pengetahuan pengguna melalui pelatihan, kurangnya tenaga yang sesuai dengan bidang rekam medis serta masih kurangnya perhatian dari pihak manajemen dalam meningkatkan kemampuan pengguna sistem informasi pelayanan rekam medis.

Rumah sakit jiwa sebagai organisasi yang memberikan pelayanan kesehatan jiwa memerlukan pengalokasian 
dana yang cukup untuk pengembangan sistem informasi pelayanan rekam medis rumah sakit agar sistem depat berjalan dengan baik. Hal ini sudah menjadi perhatian dari pihak manajemen untuk bisa diusulkan pada tahun anggaran berikutnya. Teknologi yang digunakan dalam sistem informasi pelayanan rekam medis secara teknis sudah mendukung, tapi masih terkendala dengan rusaknya jaringan internet/LAN sebagai penunjang sistem, sehingga pengelolaan data yang belum terintegrasi mengakibatkan ketersediaan informasi masih memerlukan waktu dalam pembuatan laporan. Rusaknya jaringan LAN sangat mempengaruhi kinerja sistem dan dapat berdampak pada sistem pelayanan rekam medis yang ada.

Gambaran kelebihan dan

kekurangan dari hasil penelitian yang dilaksanakan terhadap sistem informasi pelayanan rekam medis adalah sebagai berikut :

\section{Faktor Manusia}

Kelebihan, membantu dalam pekerjaan seperti pencarian data kunjungan pasien, mudah dalam pengoperasian, mudah untuk dipelajari dan menginput data, dan petugas admin membantu memberikan petunjuk penggunaan sistem (sesuai kompetensinya).

Kekurangan, petugas belum pernah mengikuti pelatihan, perlu penambahan tenaga sesuai kompetensi rekam medis, beban kerja rangkap dari petugas dan kurangnya dukungan dari pihak manajemen dalam dalam meningkatkan pengetahuan petugas dan perbaikan fasilitas penunjang sistem.

\section{Faktor Organisasi}

Kelebihan, rekam medis berada dibawah Wadir. Bidang Pelayanan Medis dan Keperawatan. Data dari rekam medis digunakan untuk pembuatan laporan kunjungan pasien dan pelayanan rumah sakit.

Kekurangan, pengembangan sistem rekam medis belum menjadi prioritas serta anggaran yang tersedia untuk pengembangan unit rekam medis seperti peningkatan SDM dan sarana penunjang lainnya belum tersedia.

\section{Faktor Teknologi (kualitas sistem,} kualitas informasi dan kualitas layanan)

Kelebihan, secara tampilan sederhana dan mudah dioperasikan serta mudah dipelajari, komputer dan laptop yang digunakan sekarang dalam kondisi baik, membantu dalam pencarian data pasien dan status perawatan, data dibagi sesuai poli serta tindakan perawatan, keamanan sistem terjamin dengan penggunaan username dan password.

Kekurangan, jaringan internet/LAN rusak rusak, data kunjungan ditiap-tiap poli terdapat kesalahan, informasi yang dihasilkan belum sesuai harapan dari segi keakuratan data, memerlukan waktu dalam pelaporan, karena data harus diperiksa ulang oleh bagian rekam medis, sistem belum terintegrasi ke bagian rekam medis, pemeliharaan sistem yang berjalan belum ada, dikarenakan anggaran belum tersedia serta beberapa komputer dan printer dalam keadaan rusak.

\section{KESIMPULAN}

Berdasarkan hasil penelitian dan pembahasan evaluasi sistem informasi pelayanan rekam medis, dapat disimpulkan sebagai berikut :

Faktor manusia, penggunaan sistem dilakukan secara rutin setiap hari kerja/jam pelayanan pasien, sumber daya manusia yang sesuai bidang keilmuan masih kurang 
dalam segi jumlah, sehingga pemberdayaan tenaga yang tidak sesuai mengakibatkan beban kerja tambahan bagi petugas penyedia layanan serta pengetahuan dan keterampilan pengguna sistem masih perlu ditingkatkan dengan mengikuti pelatihan secara khusus.

Faktor organisasi, secara umum organisasi mendukung sistem informasi pelayanan rekam medis, walaupun masih terdapat kekurangan dalam beberapa hal. Lingkungan organisasi dalam menunjang sistem perlu mengalokasikan anggaran untuk unit rekam medis dalam hal pemeliharaan dan pengembangan sistem.

Faktor Teknologi (kualitas sistem, kualitas informasi dan kualitas layanan), informasi pelayanan rekam medis belum berjalan secara maksimal karena jaringan internet yang kurang baik serta rusaknya jaringan LAN yang berdampak tidak maksimalnya kinerja sistem, petugas dan admin memback-up data menggunakan bantuan Ms. Excel dan menggunakan formulir. Kualitas informasi belum sesuai dengan apa yang diharapkan, karena petugas rekam medis harus memeriksa atau mengkaji ulang data kunjungan pasien, sehingga proses untuk menghasilkan informasi dalam pelaporan kegiatan pelayanan memerlukan waktu. Kualitas layanan belum maksimal, karena konektivitas antara bagian rekam medis dan poli bermasalah, karena jaringan LAN yang rusak dan masih kurangnya SDM yang menangani bagian rekam medis serta masih kurangnya perhatian dari pihak manajemen rumah sakit karena keterbatasan anggaran yang tersedia untuk pengadaan, peningkatan dan perbaikan sistem.

Ada ketidakcocokan antara faktor manusia, organisasi dan teknologi, seperti pengguna sistem dengan latar belakang pendidikan yang tidak sesuai dengan bidang rekam medis, belum adanya peningkatan pengetahuan dan keterampilan pengguna, masih kurangnya perhatian dari pihak manajemen dalam mengembangkan sistem informasi pelayanan rekam medis karena terkendala dengan anggaran yang tersedia serta fasilitas penunjang sistem rekam medis yang belum diperbaiki.

\section{UCAPAN TERIMA KASIH}

Dalam penelitian ini penulis banyak mendapatkan dukungan, bimbingan, masukkan dan motivasi dari berbagai pihak. Untuk itu pada kesempatan ini penulis menyampaikan ucapan terima kasih dan penghargaan yang sebesarbesarnya kepada :

Politeknik Kesehatan Kemenkes Manado yang telah memberikan kesempatan kepada penulis untuk mengembangkan diri melalui tugas belajar. Segenap manajemen Rumah Sakit Jiwa Prof. Dr. V.L. Ratumbuysang Provinsi Sulawesi Utara yang telah memberikan ijin penelitian, serta membantu penulis dalam penyelesaian penelitian.

Civitas akademika Universitas Diponegoro Program Pasca Sarjana Magister Ilmu Kesehatan Masyarakat Universitas Diponegoro yang telah memberikan ilmu yang sangat berharga bagi penulis, khususnya Konsentrasi Sistem Informasi Manajemen Kesehatan.

\section{DAFTAR PUSTAKA}

1. Kementerian Kesehatan RI.Peraturan Menteri Kesehatan. Tentang Rekam Medis. Nomor 269/Menkes/PER/III/2008.Jakarta. 2008 .

2. Depkes RI. Sistem Informasi Rumah Sakit di Indonesia (Sistem Pelaporan RS Revisi V). Departemen Kesehatan. 
Jakarta. 2003.

3. Sunyoto Danang. Sistem Informasi Manajemen Perspektif Organisasi. CAPS. Yogyakarta. 2007.

4. Annoymous.

http://www.rumahsakitpro.com/aplika si-sistem-informasi-manajemenrumah-sakit-terpadu diunduh 15 Juli 2017

5. Gunawan Indra. Evaluasi Sistem Informasi Manajemen Rumah Sakit (SIMRS) RSUD Brebes Dalam Kesiapan Penerapan Sistem Informasi Rumah Sakit (SIRS) Online Kemenkes RI. Jurnal. 2013 diunduh 14 Juli 2017.

6. Nugraheni S.W. Evaluasi Sistem Informasi Rekam Medis di RSUD Kota Surakarta dalam Mendukung Rekam Kesehatan Elektronik. Indonesian Journal On Medical Science. 2017 ; 4 diunduh 14 Juli 2017.

7. Romadoni, Mulyadi, Ervi. C. Sistem Informasi Rekam Medis Rawat Jalan pada Rumah Sakit Umum Daerah Sekayu. Seminar Perkembangan dan Hasil Penelitian Ilmu Komputer. Jurnal. 2014 diunduh 14 Juli 2017. 